\title{
Favorable conditions for Xanthomonas axonopodis infection in Eucalyptus spp.
}

\author{
Daniela A. Neves ${ }^{1}$, Lúcio M. S. Guimarães ${ }^{2}$, Hélvio G. M. Ferraz² \& Acelino C. Alfenas ${ }^{2}$ \\ ${ }^{1}$ Veracel Celulose S.A., Rodovia BA-275, Km 24, 45820-970, Eunápolis, Bahia, Brazil; ${ }^{2}$ Departamento de Fitopatologia, \\ Universidade Federal de Viçosa, 36570-900, Viçosa, MG, Brazil
}

Author for correspondence: Acelino C.Alfenas, e-mail: aalfenas@ufv.br

\begin{abstract}
Currently, Xanthomonas axonopodis is one of the main foliar pathogens for Eucalyptus spp. in Brazil. It induces leaf blight and defoliation of seedlings in the nursery and young plants in the field. However, little is known about the favorable conditions for infection. The establishment and development of bacterial leaf blight caused by $X$. axonopodis in eucalyptus was studied for different leaf ages, temperatures and leaf wetness durations. Disease severity increased with leaf age, and the highest severity was observed on the fourth pair of completely expanded leaves (from the apex to the base). A higher level of bacterial colonization was also observed on the fourth pair of leaves quantified as bacterial cells $/ \mathrm{cm}^{2}$ of leaf area. Twelve hours of free water on the leaf surface, prior to inoculation, was essential to promote a severe infection. However, with the increase in the leaf wetness duration, a decrease in disease severity was observed. The optimal temperature for disease development was $26-30^{\circ} \mathrm{C}$.
\end{abstract}

Key words: Bacterial, eucalyptus, leaf blight.

\section{INTRODUCTION}

Species of eucalyptus are extensively planted in the tropics and southern hemisphere to meet the increasing world demand of forest products, such as pulp and paper, sawlog, fence posts, electricity poles, wood for energy, and essential oils. Brazil has the largest planted area (5.1 million hectares) of eucalyptus (FAOSTAT, 2012) and the highest productivity in the world estimated at $40.1 \mathrm{~m}^{3} / \mathrm{ha} /$ year (ABRAF, 2013). Despite this high productivity, severe losses have been attributed to fungal and bacterial diseases affecting eucalyptus in the last years in the country (Alfenas et al., 2009).

More recently, bacterial infections are among the main limiting factors for propagation of susceptible eucalyptus genotypes (Gonçalves et al., 2008). Particularly, from 2003 to 2008, an estimated loss of approximately 8 million dollars, caused by Xanthomonas axonopodis bacterial leaf blight was recorded in various nurseries in Brazil (Alfenas et al., 2009). Several causes have been associated with bacterial blight of eucalyptus (Coutinho et al., 2002; Gonçalves et al., 2008; Pomella et al., 1995). However, a recent survey in several nurseries and plantations in Brazil showed that $X$. axonopodis is the most important cause of bacterial leaf disease (Hélvio G. M. Ferraz, unpublished data). The decrease in photosynthetic area by leaf lesions and intense defoliation of the plant may result in low survival and reduced growth of rooted cuttings in the field (Alfenas et al., 2009; Gonçalves et al., 2008).
Despite the increasing importance of this disease, little is known about the factors affecting the bacterial infection. Determination of the optimal conditions for infection is essential to support studies on the $X$. axonopodis - eucalyptus pathosystem and to establish control strategies, mainly by screening for resistance. Thus, in this work we studied the influence of leaf wetness duration, temperature and leaf age on the development of bacterial leaf blight caused by $X$. axonopodis in eucalypt.

\section{MATERIAL AND METHODS}

\section{Plant material}

Plants of the clone 1006 (hybrid E. grandis $\times E$. urophylla) were used in all tests and were previously characterized as susceptible to $X$. axonopodis (unpublished data). Sixty-day-old cuttings were transplanted to 2 $\mathrm{L}$ pots containing substrate (MecPlant) enriched with Superphosphate $\left(6.0 \mathrm{~kg} \mathrm{~m}^{-3}\right)$ and Osmocote ${ }^{\circledR}(19: 06: 10$ at $\left.1.5 \mathrm{~kg} / \mathrm{m}^{3}\right)$. The plants were maintained in a greenhouse and fertilized biweekly with $100 \mathrm{~mL}$ of an NPK solution (05:10:30 at $6 \mathrm{~g} / \mathrm{L})$ per plant until the plants reached the stage suitable for inoculation (45 days after transplanting).

\section{Inoculum preparation and inoculation}

For all tests, the BSC 475 isolate of $X$. axonopodis obtained from leaves of eucalyptus in southern Bahia (Gonçalves et al., 2008) was used. The bacteria were cultured in 523 medium (Kado \& Heskett, 1970) in Petri 
dishes at $28^{\circ} \mathrm{C}$. After $48 \mathrm{~h}$, saline $(0.85 \% \mathrm{NaCl})$ was added to the plates and the colonies were collected using a Drigalski strap. The bacterial suspension obtained was adjusted in a spectrophotometer (BU 640, Beckman Coulter) to optical density $\left(\mathrm{OD}_{540 \mathrm{~mm}}=0.1\right)$, which is equivalent to the concentration $1 \times 10^{8} \mathrm{cfu} \mathrm{mL}^{-1}$, obtained by serial dilution and plaque quantification $48 \mathrm{~h}$ after plating.

Unless otherwise specified, plants were incubated for $12 \mathrm{~h}$ with $36 \mu \mathrm{mol} / \mathrm{m}^{2} / \mathrm{s}$ of white light in a moist chamber at $25^{\circ} \mathrm{C}$ prior to inoculation. For inoculation, plants were sprayed with the bacterial suspension using a backpack sprayer fitted with a fan-type nozzle (1001) and a pressure regulator valve. The inoculum was evenly applied to both sides of the leaves without reaching the point of surface run-off.

\section{Disease evaluation}

The percentage of diseased area was quantified through digitized and processed images analyzed in the software QUANT (Vale et al., 2003). Unless otherwise specified, six fully expanded leaves were evaluated for each plant.

\section{Progress of bacterial leaf blight of eucalyptus}

Five plants were inoculated in a completely randomized design (CRD) experiment with 5 replications; each plant represented an experimental unit. Defoliation was assessed at 10,20,30, and 40 days after inoculation in all branches of the plant, and severity was assessed in 18 fully expanded leaves in three branches of the plant at 10 and 20 days after inoculation (dai).

\section{Disease severity in eucalyptus leaves of different ages}

Ten plants were inoculated in a CRD experiment with 10 replications; each plant represented an experimental unit. Disease severity was evaluated in the second, third and fourth pairs of fully expanded leaves, from the apex to base, in three branches of the plant at 20 dai.

\section{Quantification of CFU of Xanthomonas axonopodis in eucalyptus leaves of different ages}

Ninety plants were inoculated in a CRD experimental with a factorial design (3 leaf positions $\times$ 6 evaluation times $\times 5$ replicates), with each replicate consisting of one plant. The number of bacterial colonies was estimated on the second, third and fourth pairs of fully expanded leaves (from the apex to the base of one branch per plant) at $0,5,10,15,20$ and 25 dai using the microdrop technique (Romeiro, 2007). One branch where the second, third and fourth pairs of leaves had symptoms of bacterial infection were selected. One leaf of each phenological stage was detached from the branch, and two $1 \mathrm{~cm}$ discs were removed. The leaf discs were disinfected using alcohol (50\%) for $30 \mathrm{sec}$ and sodium hypochlorite $(2 \%)$ for $2 \mathrm{~min}$ and then washed in sterile water. Leaf tissue was macerated in microfuge tubes $(1.5 \mathrm{~mL})$ containing 500 $\mu \mathrm{L}$ of saline $(0.85 \%)$. The volume was increased to $1000 \mu \mathrm{L}$, and serial dilutions $\left(10^{-1}\right.$ to $10^{10}$ or $\left.10^{-11}\right)$ were performed. Then, $20 \mu \mathrm{L}$ of each dilution was plated on Petri dishes containing the 523 culture medium and incubated in a growth chamber at $28^{\circ} \mathrm{C}$. After eight hours, the number of colonies was counted for each dilution.

\section{Severity of leaf blight under different periods of leaf wetness after inoculation}

In order to determine the effect of leaf wetness duration after inoculation on disease severity, forty-two plants were inoculated in a split-plot CRD experiment. The whole plot represented seven wetness duration periods after inoculation $(0,3,6,12,24,48,96 \mathrm{~h})$ with six replications per treatment, and the subplots were three assessments in time (10, 15 and 20 dai). Each experimental unit consisted of one plant. After inoculation, the plants were maintained in a moist chamber according to each incubation time, under a photoperiod of $12 \mathrm{~h}\left(36 \mu \mathrm{mol} \mathrm{m} \mathrm{m}^{-2} \mathrm{~s}^{-1}\right.$ of white light). Plants were moved from the moist chamber at specific times and transferred to the greenhouse, where they remained until the end of the evaluations.

\section{Severity of leaf blight under different temperatures}

Twenty-four plants were inoculated in a split-plot CRD experiment, where the whole plot was temperature $\left(18,22,26\right.$ and $\left.30^{\circ} \mathrm{C}\right)$, with six replicates per treatment and the subplot was assessment over time $(10,15,20$ and 25 dai). Each experimental unit consisted of one plant. After inoculation and incubation for $24 \mathrm{~h}$ in a moist chamber, the plants were transferred to a growth chambers according to pre-determined temperature, under a photoperiod of $12 \mathrm{~h}$ (36 $\mu \mathrm{mol} \mathrm{m} / \mathrm{s}$ of white light), where they remained until the end of evaluations.

\section{Statistical analyses}

Statistical analyses were performed using the software SAS v.6.01 (SAS Institute Inc.) and STATISTICA v.5 (StatSoft). The values of disease severity and incidence, defoliation and bacterial colonization were subjected to linear and nonlinear regression analysis to select models that best fitted data on the disease progress curve based on the smallest sum of squares of the residue (SQR) the mean squared error (MSE) and the absence of patterns in the residuals. The logistic model provided the best fit for the progress curve of defoliation. The negative exponential model was fitted to mean severity data for each period in the moist chamber and the monomolecular model fitted to the effect of temperature.

The original data for bacterial colonization were transformed to $\log _{10}(\mathrm{cfu}+1)$. As no model gave a satisfactory fit, data were plotted on a graph of mean cfu $\mathrm{cm}^{-2}$ versus time. Leaf age effect was analysed by means of analysis of variance and the mean disease severities were compared using Fisher's LSD test at 95\%. 


\section{RESULTS}

\section{Defoliation progress}

A significant increase was found $(P \leq 0.05)$ in defoliation with increasing time after inoculation. At 10 dai, there was no defoliation, whereas at 20,30 and 40 dai, the average defoliation was $7.1,22.56$ and $27.03 \%$, respectively (Figure 1).

\section{Distribution of leaf blight symptoms on leaves of different ages}

A significant increase was found $(P \leq 0.05)$ in disease severity with increasing leaf age (Figure 2 ). The average severity in older leaves (the fourth pair of leaves from the apex to base) at 20 dai was $17 \%$, while the average in new and intermediate leaves (the second and third pairs of leaves from the apex to the base) was 0.2 and $1.7 \%$, respectively.

\section{Quantification of Xanthomonas axonopodis in leaves of different ages}

The leaf age significantly influenced the level of bacterial colonization $(P \leq 0.05)$ and disease symptoms.
There was an increase in the bacterial population in older leaves, peaking at $28.7 \times 10^{11} \mathrm{cfu} \mathrm{cm}^{-1}$ in the fourth pair of leaves at 20 days; in the youngest leaves (second and third pairs of leaves) at 20 dai, bacterial colonization was $1.22 \times 10^{6}$ and $1.33 \times 10^{10} \mathrm{cfu} \mathrm{cm}^{-1}$, respectively. However, a decrease in the bacterial population after 20 dai was observed (Figure 3). In any phenological stage of the leaves, initial disease symptoms were small chlorotic spots that evolved differently with leaf age. In young leaves, the lesions became shallow, dried, and light brown, sometimes forming small holes and occasionally having abortion injuries. In the leaves of the intermediate stage, lesions became angular, brownish, and with a dry aspect. In older leaves, the lesions become angular, interveinal, and soaked, located at the edges of the leaf blade or dispersed. Over time, these lesions coalesced, resulting in leaf browning and early defoliation.

\section{Severity of leaf blight under different periods of leaf wetness}

The duration of leaf wetness significantly $(P \leq 0.05)$ influenced the severity of leaf blight disease in eucalyptus.
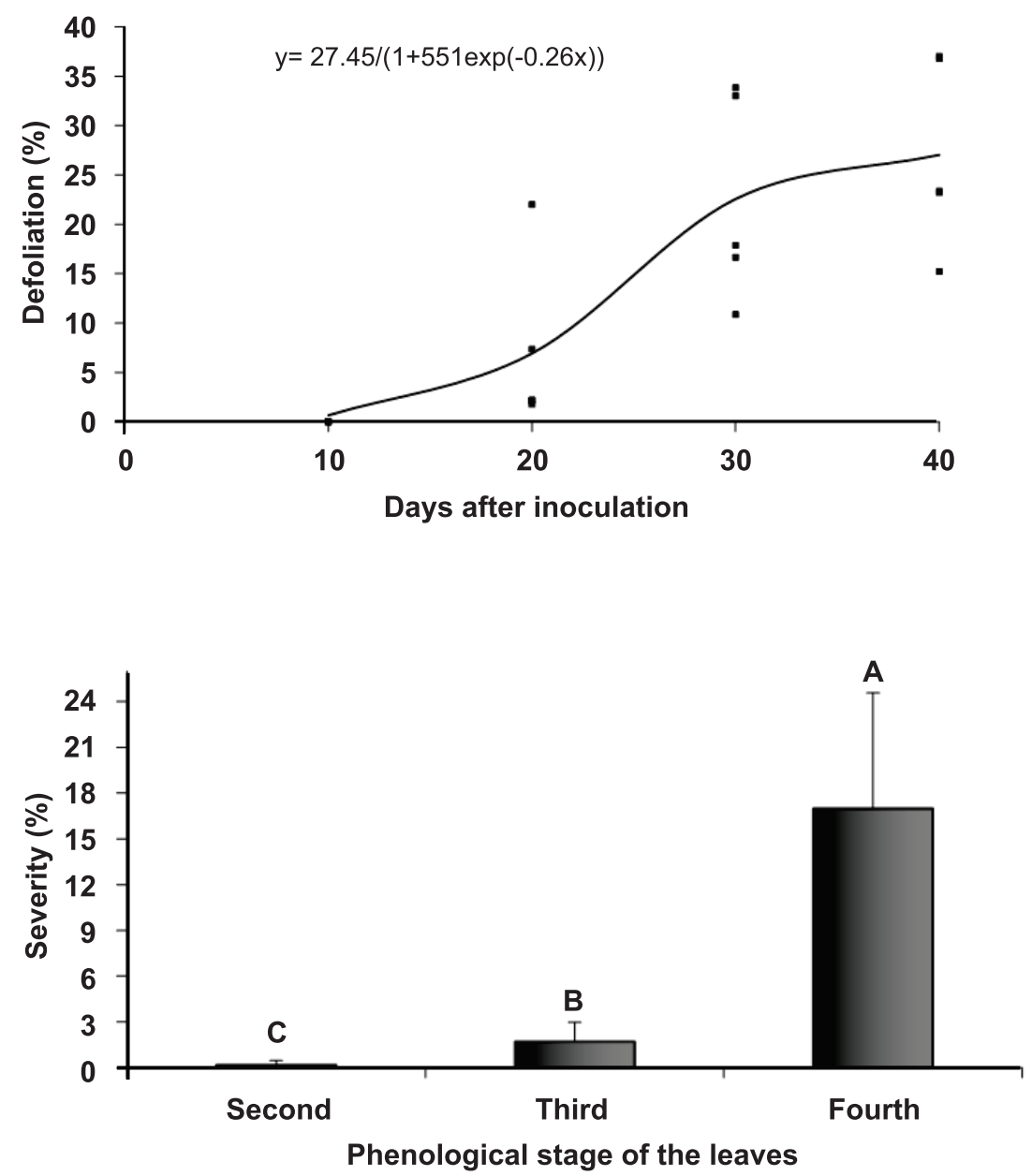

FIGURE 1. Progress of defoliation caused by Xanthomonas axonopodis in plants of the clone 1006, hybrid of Eucalyptus grandis $\times E$. urophylla.
FIGURE 2 - Severity of leaf blight caused by Xanthomonas axonopodis in plants of the clone 1006, hybrid of Eucalyptus grandis $\times$ E. urophylla, on leaves of different growth stages (second, third and fourth pair of leaves from the apex to the base). Means followed by the same letter were not significantly different using Fisher's test (LSD; $P$ $\leq 0.05)$. 
A decrease in severity with increasing duration of leaf wetness was observed in all evaluations (Figure 4). The average severity at 30 dai, was $12.8 \%$ for plants not kept in a moist chamber $(0 \mathrm{~h})$ and $6.1 \%$ for plants kept in a moist chamber for $3 \mathrm{~h}$. For plants kept in a moist chamber for 48 and 96 h, severity was 4.3 and 3.2\%, respectively. Control plants, kept in a greenhouse in the absence of leaf wetness pre-and post-inoculation, had a mean severity of $1.2 \%$ at 30 dai.

\section{Severity of leaf blight at different temperatures}

The temperature significantly $(P \leq 0.05)$ influenced the severity of disease in eucalyptus. Except at $22^{\circ} \mathrm{C}$, the rate of disease progression increased with increasing temperatures (Figure 5). At $22^{\circ} \mathrm{C}$, the plants also exhibited a high incidence of rust, which may have adversely affected the bacterial infection and made evaluations more difficult.

\section{DISCUSSION}

This study showed that development of leaf blight caused by $X$. axonopodis in eucalyptus is influenced by the age of the leaf, duration of leaf wetness, and temperature.
Percent defoliation increased significantly over time, with the maximum defoliation at 40 dai. Defoliation was due to high disease severity, where lesions coalesced, culminating in overall leaf browning and early leaf fall.

Leaf age significantly affected the colonization and development of symptoms caused by $X$. axonopodis. At 20 dai, older leaves showed a higher percentage of leaf area with lesions and bacterial colonization $\left(\mathrm{cfu} / \mathrm{cm}^{2}\right)$. At 25 dai, there was a decrease in the bacterial population for the three growth stages of leaves, most likely due to the defoliation of leaves exhibiting greater disease severity.

At 25 dai, there was a reduction in the bacterial population for the three growth stages of leaves, most likely due to defoliation of leaves that exhibited greater disease severity. This observation could also be due to the destructive sampling in this experiment. The effect of leaf age on disease severity has been studied in other pathosystems. In contrast to results of this study, Stall et al. (1982) and Gottwald \& Graham (1992) found that young leaves of Citrus sp. were the most susceptible to citrus canker, caused by $X$. axonopodis pv. citri. Similarly, in the pathosystem, Erwinia amylovora $\times$ Malus sp., resistance to
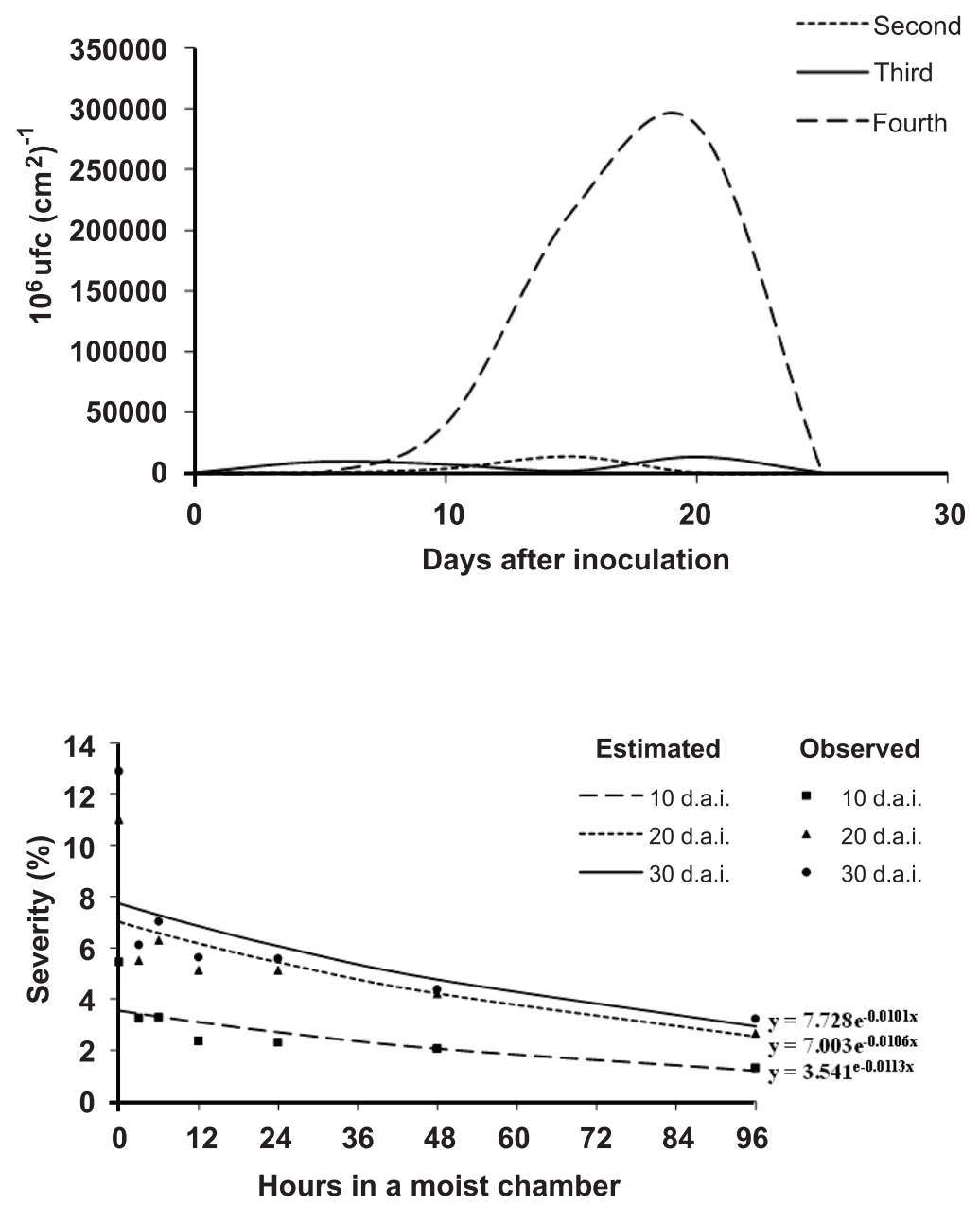

FIGURE 3 - Bacterial colonization of Xanthomonas axonopodis on leaves of different growth stages (second, third and fourth pair of leaves from the apex to the base) of the clone 1006, hybrid of Eucalyptus grandis $\times E$. urophylla.
FIGURE 4 - Severity of leaf blight in plants of the clone 1006, hybrid of Eucalyptus grandis $\times$ E. urophylla, caused by Xanthomonas axonopodis with different durations of leaf wetness after inoculation. Each point represents the mean of six replications. 


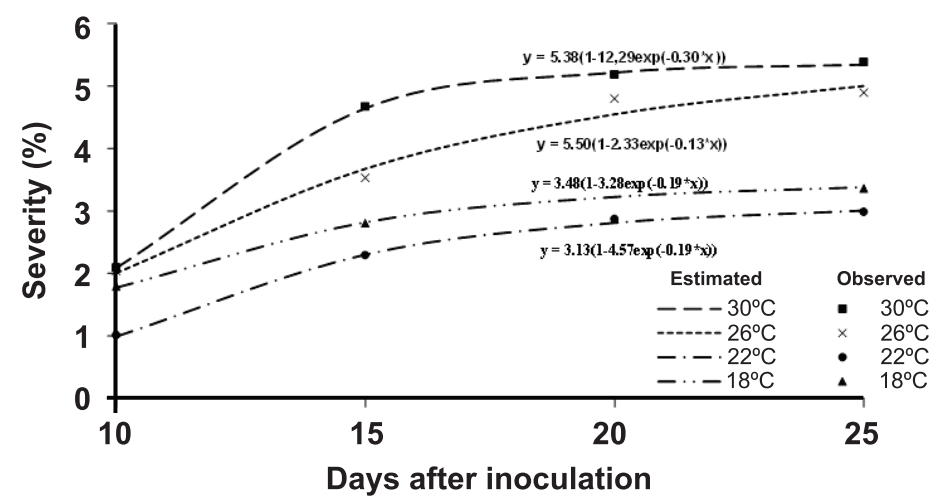

FIGURE 5 - Severity of leaf blight in plants of the clone 1006, hybrid of Eucalyptus grandis $\times$ E. urophylla, caused by Xanthomonas axonopodis at different temperatures. Each point represents the mean of six replications. infection increased with leaf age (Crosse et al., 1972).

Silva (2007) observed that an increase in stomatal density was accompanied by an increase in the severity of $X$. axonopodis in eucalyptus plants; young leaves generally showed no infection due to the low density of stomata, which supports our results. However, there are other factors that may be related to the susceptibility of leaves to pathogens. The lower disease severity in young eucalyptus leaves can be explained by the greater accumulation of waxes, which hamper the wetness and therefore infection, because bacteria require water to spread, multiply and penetrate into host tissues. According to Graham et al. (1992), leaf characteristics that influence the infiltration of water and soaked leaf tissue are the most important for successful infection of the pathogen.

The different symptoms observed in different growth stages of leaves on the plant may be affected by post-infectious events. The amount and type of phenolic compounds that occur in leaves of different ages can inhibit bacterial growth (Li \& Steffens, 2002). However, the mechanisms involved in the pathogenesis of $X$. axonopodis - eucalyptus are unknown. In this study, we used only one clone (1006), and observations for inoculations using different clones suggest that the pattern of symptoms can change between different clones and, or species of Eucalyptus. For example, the clones 37254 (E. urophylla $\times$ E. globulus) and 6061 (E. grandis $\times$ E. urophylla) have more susceptible young leaves (Lúcio MS Guimarães, personal observation).

The presence of free water on the leaf surface is essentialforthepenetrationandmovementofplantpathogenic bacteria in their host; they penetrate using natural openings, such as stomata (Beattie \& Lindow, 1999; Hirano \& Upper, 1983; Romeiro, 2007). In nurseries, bacterial leaf blight attacks spray-irrigated seedlings most intensely (Alfenas et al., 2009). This agrees with our results that there was a low severity of disease in plants that were not allowed to have leaf wetness pre-inoculation and demonstrates the need for a water slide on the leaf surface for the establishment of blight in eucalyptus plants. However, a decrease in severity of disease was observed with increasing leaf wetness duration post-inoculation. Similar results were found by Fukui et al. (1999) for the pathosystem, X. axonopodis pv. dieffenbachiae $\mathrm{x}$ Anthurium, and they concluded that the presence of water on the leaf surface is only essential at the stage of pathogen invasion and not after the infection and colonization of bacteria. Furthermore, studies have shown that, in other pathosystems, longer periods of wetness after inoculation favor increased disease severity (Zerh et al., 1996; Pria et al., 2006).

The inverse relationship between leaf wetness after inoculation and disease severity for the pathosystem $X$. axonopodis - eucalyptus can be explained by the fast penetration of the bacteria in favorable conditions and subsequent washing of the inoculum with increasing wetness duration, resulting in lower rates of infection by the pathogen. Under nursery conditions in Guaiba (state of Rio Grande do Sul, Brazil), three eucalyptus clones were observed to have a higher incidence of $X$. axonopodis infection in sprinkler-irrigated seedlings than those under sub-irrigation or temporary flood (A.C. Alfenas, unpublished data). Sprinkler irrigation, in addition to allowing the formation of a water film on the leaf, also favors the spread of the pathogen through the splash of droplets containing bacterial cells (Romeiro, 2007).

Higher temperatures caused an increase in the severity of disease caused by $X$. axonopodis in eucalyptus. The optimal temperature range for the development of the disease is between 26 and $30^{\circ} \mathrm{C}$. Temperatures below this range retarded the development of the disease. However, plants held at $22^{\circ} \mathrm{C}$ had a lower percentage of leaf area with lesions than at $18^{\circ} \mathrm{C}$, which could be explained by the high incidence of rust (Puccinia psidii) in plants held at $22^{\circ} \mathrm{C}$. It was observed that the pustules of $P$. psidii overlapped lesions caused by $X$. axonopodis. Similar studies report that the severity of symptoms caused by bacterial diseases increases with increasing temperatures (Zerh et al., 1996; Fukui et al., 1999; Pria et al., 2006). The greater severity of $X$. axonopodis in eucalyptus plants at high temperatures is consistent with observations in vitro suggesting that the metabolism of the bacteria is accelerated at higher temperatures and decreases significantly at lower temperatures (A.C. Alfenas, 
unpublished data). These findings are also consistent with observations in forest nurseries, where a greater severity of bacterial blight occurs in warmer seasons.

The results of this study indicate that: $(i)$ assessments of disease severity should be performed at 20 dai, while defoliation assessments should be conducted from 30 dai; (ii) older leaves of eucalyptus (the fourth pair of leaves from the apex to base) exhibit higher bacterial colonization (cfu $\mathrm{mL}^{-1}$ ) and severity; (iii) leaf wetness pre-inoculation is critical to the development of the disease and the results suggest that longer periods of leaf wetness after inoculation lowers severity; and $(v)$ the optimum temperature range for the development of the disease is between $26-30^{\circ} \mathrm{C}$.

\section{ACKNOWLEDGEMENTS}

The authors thank Conselho Nacional de Desenvolvimento Científico e Tecnológico - CNPq and Fundação de Amparo à Pesquisa do Estado de Minas Gerais - FAPEMIG for supporting and financing this research.

\section{REFERENCES}

ABRAF (2013) Anuário estatístico da Associação Brasileira de Produtores de Florestas Plantadas 2011: ano base 2012. Brasília, DF, Brazil. ABPFP.

Alfenas AC, Zauza EAV, Mafia RG, Assis TF (2009) Clonagem e doenças do eucalipto. $2^{\text {nd }}$ Ed. Viçosa, MG, Brazil. Editora UFV.

Beattie GA, Lindow SE (1999) Bacterial colonization of leaves: A spectrum of strategies. Phytopathology 89:353-359.

Coutinho T, Preisig O, Mergaert J, Cnockaert MC, Riedel KH, Swuings J, Wingfield MJ (2002) Bacterial blight and dieback of Eucalyptus species, hybrids, and clones in South Africa. Plant Disease 86:20-25.

Crosse JE, Goodman RN, Shaffer Junior WH (1972) Leaf damage as a predisposing factor in the infection of apple shoots by Erwinia amylovora. Phytopathology 62:176-182.

FAOSTAT (2012) Food and Agriculture Organization of the United Nations. Available at:http://faostat.fao.org/site/567/ DesktopDefault.aspx?PageID=567. Accessed on May 10, 2013.

Fukui R, Fukui H, Alvarez AM (1999) Effect of temperature on the incubation period and leaf colonization in bacterial blight of
Anthurim. Phytopathology 89:1007-1014.

Gonçalves RC, Lau D, Oliveira JR, Maffia LA, Cascardo JCM, Alfenas AC (2008) Etiology of bacterial leaf blight of eucalyptus in Brazil. Tropical Plant Pathology 33:180-188.

Graham JH, Gottwald TR, Riley TD, Achor D (1992) Penetration through leaf stomata and strains of Xanthomonas campestris in citrus cultivars varying in susceptibility to bacterial diseases. Phytopathology 82:1319-1325.

Gottwald TR, Graham JH (1992) A device for precise and nondisruptive stomatal inoculation of leaf tissue with bacterial pathogens. Phytopathology 82:930-935.

Hirano SS, Upper CD (1983) Ecology and epidemiology of foliar bacterial plant pathogens. Annual Review of Phytopathology 21:243-270.

Kado EI, Heskett MG (1970) Selective media for isolation of Agrobacterium, Corynebacterium, Erwinia, Pseudomonas and Xanthomonas. Phytopathology 60:969-976.

Li L, Steffens JC (2002) Overexpression in polyphenol oxidase in transgenic tomato plants results in enhanced bacterial disease resistance. Planta 215:239-24.

Pomella AWV, Romeiro RS, Ferreira FA, Oliveira JR (1995) Lesões foliares em viveiro de eucalipto incitadas por uma espécie fluorescente de Pseudomonas. Fitopatologia Brasileira 20:374. (Abstract)

Pria MD, Christiano RCS, Furtado EL, Amorim L, Bergamin Filho A (2006) Effects of temperature and leaf wetness duration on infection of sweet oranges by Asiatic citrus canker. Plant Pathology 55:657-663.

Romeiro RS (2007) Bactérias Fitopatogênicas. $2^{\text {nd }}$ Ed. Viçosa, MG, Brazil. Editora UFV.

Silva, AG (2007) Histopatologia e influência de nutrientes na intensidade da bacteriose foliar do eucalipto causada por Xanthomonas axonopodis. Doctoral Thesis, Universidade Federal de Viçosa. Viçosa, MG, Brazil.

Stall RE, Marco GM, Canteros De Echenique BI (1982) Importance of mesophyll in mature leaf resistance to cancrosis of citrus. Phytopathology 72:1097-1100.

Vale FXR, Fernandes Filho EI, Liberato JR (2003) Quant: A software plant disease severity assessment. In: $8^{\text {th }}$ International Congress of Plant Pathology. Abstracts... Christchurch, New Zealand. ISPP.

Zerh E, Shepard DP, Bridges WC (1996) Bacterial spot of peach as influenced by water congestion, leaf, wetness duration, and temperature. Plant Disease 80:339-341.

TPP-2014-0079

Submitted: 29 May 2014

Revisions requested: 25 July 2014

Accepted: 15 August 2014

Section Editor: Silvaldo Felipe da Silveira 